\title{
PERAN PEMERINTAH DALAM PENGENTASAN KEMISKINAN DI KABUPATEN CIAMIS
}

\author{
Oleh : \\ Nina Herlina, S.H., M.H. dan Mamay Komariah, S.H., M.H. *)
}

\begin{abstract}
Poverty is a complex phenomenon that is multidimensional. The wide area of Ciamis Regency and the different characteristics of poverty require different poverty strategies. The pockets of poverty in Kabupaten Ciamis are generally located in rural areas and remote areas.

The role of Government in alleviating poverty in Kabupaten Ciamis is in the form of Integrated Services Poverty Reduction Area with the legal basis Regent Regulation Ciamis No. 62 of 2014 on the Establishment of Integrated Services Poverty Reduction Area and make policy of poverty reduction in Kabupaten Ciamis.

The obstacles faced by the government in poverty alleviation in Kabupaten Ciamis, among others, in the case of regional poverty data management system is not centralized only in districts, but for the management of poverty funds required devices and systems integrated into the kecamatan and village, so that the number of poor communities valid in accordance with the reality in the field.

The local government of Kabupaten Ciamis issued a regulation concerning poverty alleviation namely Regional Regulation of Ciamis Regency Number 11 of 2016 on Poverty Reduction, Regulation of Ciamis Regent Number 29 of 2016 on Local Indicators of Poor Family in KabupatenCiamis, and realize 3 (Three) main health program, "Waluya", Educational Field "Calaka", Social Economy "Walagri".
\end{abstract}

Keywords : Alleviation, Poverty.

\section{ABSTRAK}

Kemiskinan merupakan fenomena yang kompleks yang bersifat multidimensi. Luasnya wilayah Kabupaten Ciamis dan karakteristik kemiskinan yang berbeda membutuhkan strategi kemiskinan yang berbeda pula. Kantong-kantong kemiskinan di Kabupaten Ciamis yang pada umumnya berada pada wilayah perdesaan dan daerah-daerah terpencil.

Peran Pemerintah dalam pengentasan kemiskinan di Kabupaten Ciamis yaitu dengan di bentuknya Layanan Terpadu Penanggulangan Kemiskinan Daerah LTPKD dengandasarhukum Peraturan Bupati Ciamis Nomor 62 Tahun 2014 tentang Pembentukan Layanan Terpadu Penanggulangan Kemiskinan Daerah serta membuat kebijakan penanggulangan kemiskinan di Kabupaten Ciamis.

Kendala yang dihadapi pemerintah dalam pengentasan kemiskinan di Kabupaten Ciamis antara lain dalam hal sistem pengelolaan data kemiskinan daerah tidak terpusat hanya di kabupaten saja tetapi untuk pengelolaan dana kemiskinan diperlukan perangkat dan sistem yang terintegrasi hingga ke kecamatan dan desa, agar jumlah masyarakat miskin valid sesuai dengan kenyataan di lapangan.

\footnotetext{
${ }^{*)}$ Dosen Tetap Fakultas Hukum Unigal
} 
Pemerintah daerah Kabupaten Ciamis mengeluarkan regulasi mengenai pengentasan kemiskinan yakni Peraturan Daerah Kabupaten Ciamis Nomor 11 Tahun 2016 Tentang Penanggulangan Kemiskinan, Peraturan Bupati Ciamis Nomor 29 Tahun 2016 tentang Indikator Lokal Keluarga Miskin di Kabupaten Ciamis, serta merealisasikan 3 (Tiga) program utama yakni, Bidang Kesehatan "Waluya", Bidang Pendidikan "Calaka", Bidang Sosial Ekonomi "Walagri".

Kata kunci : Pengentasan, Kemiskinan.

\section{PENDAHULUAN}

\section{A. Latar Belakang}

Kemiskinan merupakan masalah lama yang pada umumnya dihadapi hampir di semua negara-negara berkembang, terutama negara yang padat penduduknya seperti Indonesia. Kemiskinan seharusnya menjadi masalah bersama yang harus ditanggulangi secara serius, kemiskinan bukanlah masalah pribadi, golongan bahkan pemerintah saja, akan tetapi hal ini merupakan masalah setiap kita warga negara Indonesia.

Peran itu dapat dilihat dari sikap pemerintah dalam menyelesaikannya. Peran pemerintah adalah sebagai pengatur kebijakan masalah pembangunan ekonomi, pemerintah juga yang mengatur bagaimana pelaksanaan rancangan pembangunan, apakah sesuai dengan rencana yang telah dibuat. Peran pemerintah adalah sebagai pengendali. Dalam upaya untuk menyeimbangkan pertumbuhan sebagai sektor perekonomian hingga jumlah keluarga miskin dapat berkurang, dibutuhkan pengawasan dan pengaturan oleh negara atau pemerintah dalam upaya mencapai pertumbuhan yang seimbang, karena keseimbangan membutuhkan pengawasan terhadap produksi, distribusi dan dan komoditas.

Untuk memastikan tercapainya target penurunan angka kemiskinan tersebut tidak saja diperlukan political will dari pemerintah saja, akan tetapi juga dari seluruh komponen masyarakat. Penanggulangan kemiskinan bukan merupakan proses instant dan mudah, namun harus sustainable dan memerlukan pendekatan yang sistematik. Pemerintah daerah perlu mempunyai kebijaksanaan.

Fokus pengentasan kemiskinan menjadi mendesak dan yang lebih penting lagi adalah upaya menekan angka kemiskinan tersebut dilakukan secara konkrit, tepat sasaran dan komprehensif. Dengan demikian, upaya 
penanggulangan kemiskinan di pedesaan dan perkotaan diharapkan dapat terwujud secara selaras.

Kabupaten Ciamis yang merupakan daerah agraris sehingga dapat dilihat dari mayoritas penduduk kabupaten Ciamis bermatapenceharian sebagai petani. Adanya beberapa kelompok buruh yang ada di Kabupaten Ciamis salah satumya akibat dari kelompok yang tidak punya tanah yang cukup untuk di garap. Tingkat kemiskinan di Kabupaten Ciamis cenderung menurun hal ini bisa dilihat dari data Hasil Pemutakhiran Basis Data Terpadu (PBDT) 2015 meskipun hal tersebut tidak signifikan.

Upaya terencana untuk meningkatkan kapasitas daerah dalam mewujudkan masa depan daerah yang lebih baik dan kesejahteraan bagi semua masyarakat. Hal ini sejalan dengan amanat Undang-Undang Nomor 13 Tahun 2011 tentang Penanganan Fakir Miskin. Penyelenggaraan tentang Pemerintahan Daerah didasari pada Undang-Undang Nomor 23 Tahun 2014 Tentang Pemerintahan Daerah. Selaras dengan itu Pemerintah Kabupaten Ciamis mengeluarkan Peraturan Daerah Nomor 11 Tahun 2016 tentang Penanggulangan Kemiskinan.

Secara umum kinerja Pemerintah Kabupaten Ciamis dapat dilihat dari upaya pemberdayaan sumber daya manusia sebagai modal utama pembangunan. Adanya Lembaga Pemerintah yakni Layanan Terpadu Penanggulangan Kemiskinan Daerah (LTPKD) berdasarkan hukum Peraturan Bupati Ciamis Nomor 62 Tahun 2014 tentang Pembentukan Layanan Terpadu Penanggulangan Kemiskinan Daerah.

Berdasarkan latar belakang diatas, maka penelitian yang dilakukan penulis di batasi dengan rumusan masalah sebagai berikut, Sejauhmanakah peran pemerintah dalam pengentasan kemiskinan di Kabupaten Ciamis? Kendala-kendala apa saja yang timbul dalam pengentasan kemiskinan di Kabupaten Ciamis? Bagaimana upaya pemerintah dalam pengentasan kemiskinan di Kabupaten Ciamis ?

Adapun Penelitian ini dilakukan dengan berbagai tujuan yang hendak dicapai, tujuan tersebut yakni, sebagai pelaksanaan Tridarma Perguruan Tinggi yang merupakan kewajiban Dosen untuk menyumbangkan pemikiran di bidang IImu Hukum guna memecahkan persoalan khususnya dalam Peran pemerintah dalam pengentasan kemiskinan di Kabupaten Ciamis, memberi pemahaman 
kepada Masyarakat tentang peran pemerintah dalam pengentasan kemiskinan di Kabupaten Ciamis, menganalisis dan mengoptimalkan terhadap kendalakendala dan upaya dari pemerintah dalam pengentasan kemiskinan di Kabupaten Ciamis.

Penelitian ini dilakukan dengan harapan dapat memberikan manfaat sebagai berikut : Bagi Pemerintah Daerah dapat memberikan kontribusi mengenai peran pemerintah dalam pengentasan kemiskinan di Kabupaten Ciamis dan memberi pemahaman mengenai kendala-kendala dan upaya dari pemerintah dalam pengentasan kemiskinan di Kabupaten Ciamis. Bagi Masyarakat memberikan pengetahuan tentang peran pemerintah dalam pengentasan kemiskinan di Kabupaten Ciamis.

Metode penelitian ini menggunakan metode pendekatan Yuridis Sosiologis (social legal approach), yang memandang hukum sebagai fenomena sosial, yang dalam interaksinya tidak lepas dari faktor-faktor non hukum dalam lingkungannya sebagai faktor sosial, politik dan ekonomi, budaya, psikologi dan sebagainya, sehingga hukum tidak di pandang sebagi suatu norma yang tertutup dan otonom, namun memiliki keterikatan yang erat dengan variabelvariabel lain, non hukum. (Ronny Hanitijo Soemitro;1992 ; 35).

Dalam teknik pengumpulan data yang digunakan adalah Studi kepustakaan (Library Research) yaitu pengumpulan bahan dan data-data dari peraturan perundang-undangan yang berkaitan dengan permasalahan yang dibahas. Studi lapangan (Field Research) yaitu melalui Wawancara langsung pada pihak-pihak terkait yaitu Pemerintah Kabupaten Ciamis dalam hal ini LTPKD Kabupaten Ciamis.

\section{KAJIAN PUSTAKA}

\subsection{Kemiskinan}

\subsubsection{Definisi Kemiskinan}

Kemiskinan adalah keadaan dimana terjadi kekurangan hal-hal yang biasa untuk dipunyai seperti makanan, pakaian, tempat berlindung dan air minum, hal hal ini berhubungan erat dengan kualitas hidup. Kemiskinan kadang juga berarti tidak adanya akses terhadap pendidikan dan pekerjaan yang mampu mengatasi masalah kemiskinan dan mendapatkan kehormatan yang layak sebagai warga negara. 
Kemiskinan merupakan masalah global, sebagian orang memahami istilah ini secara subyektif dan komparatif, sementara yang lainnya melihatnya dari segi moral dan evaluatif, dan yang lainya lagi memahaminya dari sudut ilmiah yang telah mapan. Istilah "negara berkembang" biasanya digunakan untuk merunjuk kepada negaranegara yang "miskin" (Criswardani Suryawati, 2005 : 18).

Kemiskinan dipahami dalam berbagai cara. Pemahaman utamanya mencakup :

1) Gambaran kekurangan materi, yang biasanya mencakup kebutuhan pangan sehari-hari, sandang, perumahan, dan pelayanan kesehatan. Kemiskinan dalam arti ini dipahami sebagai situasi kelangkaan barang-barang dan pelayanan dasar.

2) Gambaran tentang kebutuhan sosial, termasuk keterkucilkan sosial, ketergantungan, dan ketidakmapuan untuk berpartisipasi dalam masyarakat. Hal ini termasuk pendidikan dan informasi. Keterkucilkan sosial biasanya dibedakan dari kemiskinan, karena hal ini mencakup masalah-masalah politik dan moral, dan tidak dibatasi pada bidang ekonomi.

3) Gambaran tentang kurangnya penghasilan dan kekayaan yang memadai, makna "memadai" disini sangat berbeda-beda melintas bagian-bagian politik dan ekonomi di seluruh dunia.

BAPPENAS (Badan Perencanaan dan Pembangunan Nasional) mendefinisikan kemiskinan sebagai situasi serba kekurangan yang terjadi bukan karena kehendak si miskin, melainkan karena keadaan yang tidak dapat dihindari dengan kekuatan yang ada padanya. Kemiskinan ini ditandai oleh sikap dan tingkah laku yang menerima keadaan yang seakan-akan tidak dapat diubah yang tercermin di dalam lemahnya kemauan tetap untuk maju, rendahnya kualitas sumber daya manusia, lemahnya nilai tukar hasil produksi, rendahnya produktifitas, terbatasnya modal yang dimiliki berpartisipasi dalam pembangunan.

\subsubsection{Macam-macam Kemiskinan}

Mengamati secara mendalam tentang kemiskinan dan penyebabnya akan muncul berbagai tipologi dan dimensi kemiskinan 
karena kemiskinan itu sendiri multikompleks, dinamis, dan berkaitan dengan ruang, waktu serta tempat dimana kemiskinan dilihat dari berbagai sudut pandang. Kemiskinan dibagi dalam dua kriteria yaitu kemiskinan absolut dan kemiskinan realtif.

Kemiskinan absolut adalah kemiskinan yang diukur dengan tingkat pendapatan yang dibutuhkan untuk memenuhi kebutuhan dasarnya sedangkan kemiskinan realtif adalah penduduk yang telah memiliki pendapatan sudah mencapai kebutuhan dasar namun jauh lebih rendah dibanding keadaan masyrakat sekitarnya. Kemiskinan menurut tingkatan kemiskinan adalah kemiskinan sementara dan kemiskinan kronis.

Lain halnya menurut Sumodiningrat (1989:65) yang mengemukakan bahwa kemiskinan memiliki beberapa macam yaitu adalah sebagai berikut :

1. Kemiskinan absolut: apabila tingkat pendapatanya di bawah "garis kemiskinan" atau jumlah pendapatannya tidak cukup untuk memenuhi kebutuhan minimum, antara lain kebutuhan pangan, sandang, kesehatan, perumahan, dan pendidikan yang diperlukan untuk bisa hidup dan bekerja.

2. Kemiskinan relatif: kondisi dimana pendapatanya berada pada posisi di atas garis kemiskinan, namun relatif lebih rendah dibanding pendapatan masyrakat sekitarnya.

3. Kemiskinan kultural: karena mengacu kepada persoalan sikap seseorang atau masyarakat yang disebabkan oleh faktor budaya, seperti tidak mau berusaha untuk memperbaiki tingkat kehidupan, malas, pemboros, tidak kreatif, meskipun ada usaha dari pihak luar untuk membantunya.

4. Kemsikinan struktural: kondisi atau situasi miskin karena pengaruh kebijakan pembangunan yang belum menjangkau seluruh masyarakat sehingga menyebabkan ketimpangan.

\subsubsection{Penyebab Kemiskinan}

Terdapat beberapa faktor yang dinilai sebagai sebab-sebab kemiskinan antara lain : 
(1) Kesempatan kerja, dimana seseorang itu miskin karena menganggur, sehingga tidak memperoleh penghasilan atau kalau bekerja tidak penuh, baik dalam ukuran hari, minggu, bulan maupun tahun,

(2) Upah gaji dibawah minimum,

(3) Produktivitas kerja yang rendah,

(4) Ketiadaan aset,

(5) Diskriminasi,

(6) Tekanan harga,

(7) Penjualan tanah (Handayani; 2006).

Kuncoro menjelaskan dalam bukunya bahwa Penyebab kemiskinan sebagai berikut : (Kuncoro; 2000 : 107)

1. Secara makro, kemiskinan muncul karena adanya ketidaksamaan pola kepemilikan sumber daya yang menimbulkan distribusi pendapatan timpang, penduduk miskin hanya memiliki sumber daya dalam jumlah yang terbatas dan kualitasnya rendah.

2. Kemiskinan muncul akibat perbedaan kualitas sumber daya manusia karena kualitas sumber daya manusia yang rendah berarti produktifitas juga rendah, upahnya pun rendah.

3. Kemiskinan muncul sebab perbedaan akses dan modal.

Teori Kemiskinan Sharp, et al (1996) dalam Mudrajat Kuncoro (2004) mencoba mengidentifikasikan penyebab kemiskinan dipandang dari sisi ekonomi.

Teori ini ditemukan oleh Ragnar Nurkse (1953) dalam Kuncoro, 2004, yang mengatakan : "a poor country is poor because it is poor" (Negara miskin itu miskin karena dia miskin). Adanya keterbelakangan, ketidaksempurnaan pasar, dan kurangnya modal menyebabkan rendahnya produktivitas. Rendahnya produktivitas mengakibatkan rendahnya pendapatan yang mereka terima. Rendahnya pendapatan akan berimplikasi pada rendahnya tabungan dan investasi. Rendahnya investasi berakibat pada keterbelakangan.

Oleh karena itu, setiap usaha untuk mengurangi kemiskinan seharusnya diarahkan untuk memotong lingkaran dan perangkap 
kemiskinan ini (Mudrajad Kuncoro, 2004). Berikut gambar lingkaran setan kemiskinan (vicious circle of poverty).

\subsection{Peran Pemerintah}

\subsubsection{Definisi Peran}

Menurut Abu Ahmadi (1982) peran adalah suatu kompleks pengharapan manusia terhadap caranya individu harus bersikap dan berbuat dalam situasi tertentu yang berdasarkan status dan fungsi sosialnya. Pengertian peran menurut Soerjono Soekanto (2002:243), yaitu peran merupakan aspek dinamis kedudukan (status), apabila seseorang melaksanakan hak dan kewajibannya sesuai dengan kedudukannya, maka ia menjalankan suatu peranan.

Dari hal diatas lebih lanjut kita lihat pendapat lain tentang peran yang telah ditetapkan sebelumnya disebut sebagai peranan normatif. Sebagai peran normatif dalam hubungannya dengan tugas dan kewajiban dalam penegakan hukum mempunyai arti penegakan hukum secara Total enforcement, yaitu penegakan hukum secara penuh, (Soerjono Soekanto 1987: 220).

Sedangkan peran ideal, dapat diterjemahkan sebagai peran yang diharapkan dilakukan oleh pemegang peranan tersebut.

Dalam kerangka besar, organisasi masyarakat, atau yang disebut sebagai struktur sosial, ditentukan oleh hakekat (nature) dari peran-peran ini, hubungan antara peran-peran tersebut, serta distribusi sumberdaya yang langka di antara orang-orang yang memainkannya. Masyarakat yang berbeda merumuskan, mengorganisasikan, dan memberi imbalan (reward) terhadap aktivitas-aktivitas mereka dengan cara yang berbeda, sehingga setiap masyarakat memiliki struktur sosial yang berbeda pula.

Dengan demikian perangkat peran adalah kelengkapan dari hubungan-hubungan berdasarkan peran yang dimiliki oleh orang karena menduduki status-status sosial khusus. Peran yang dimaksud dalam penelitian ini adalah perilaku seseorang sesuai dengan status kedudukannya di masyarakat. Jadi dapat 
disimpulkan bahwa peran adalah suatu aspek yang dinamis berupa tindakan atau perilaku yang dilaksanakan oleh orang atau badan lembaga yang menempati atau memangku suatu posisi dalam situasi sosial.

\subsubsection{Kebijakan Pemerintah}

Langkah-langkah kebijakan penanggulangan kemiskinan dilakukan baik oleh Pemerintah Pusat maupun oleh Pemerintah daerah. Kebijakan pemerintah dalam pengentasan kemiskinan di Pusat terdiri dari 3 (tiga) program yakni :

a. Bidang Kesehatan

Nama Program Indonesia Sehat, Penyelenggara Badan Penyelenggara Jaminan Sosial, Media Kartu Indonesia Sehat, Cakupan Hingga Satuan Tingkat Desa (POSYANDU), Penerimaan Masyarakat kurang Mampu yang telah memiliki BPJS PBI ditambahkan kelompok Penyandang Masalah Kesejahteraan Sosial (PMKS) serta bayi baru lahir.

b. Bidang Pendidikan

Nama Program Indonesia Pintar, Media Kartu Indonesia Pintar Penerimaan Semua Anak SD/MI, SMP/MTs, SMA/MA, SMK/MAK, yang berasal dari keluarga pemegang KKS/KPS, PKH, Panti Asuhan dan Anak Yatim Piatu. Masyarakat kurang Mampu yang telah memiliki BPJS PBI ditambahkan kelompok Penyandang Masalah Kesejahteraan Sosial (PMKS) serta bayi baru lahir, Bentuk Penyalura Simpanan Tabungan di Kantor POS atau Bank yang ditunjuk bisa dicairkan atau tetap disimpan.

c. Bidang Sosial Ekonomi

Nama Program Kesejahteraan Sosial, Media Kartu Kesejahteraan Sosial (KKS), Penerimaan keluarga kurang mampu di seluruh Indonesia, mencakup juga penghuni panti asuhan, panti jompo, dan panti sosial lainnya, Besaran Rp. 200.000,-/Keluarga/Bulan. Bentuk Penyaluran Simpanan/ 
Tabungan di Kantor POS atau Bank yang ditunjuk bisa dicairkan atau tetap disimpan.

\section{HASIL PENELITIAN DAN PEMBAHASAN}

\section{Peran Pemerintah Dalam Pengentasan Kemiskinan Di Kabupaten Ciamis}

Kemiskinan merupakan fenomena yang kompleks yang bersifat multidimensi. Upaya penanggulangan kemiskinan yang selama ini dilakukan lebih bersifat spasial atau pendekatan sektoral ternyata kurang memberikan hasil yang optimal.

Analisis penyebab kemiskinan ini menggunakan pendekatan kombinasi kultural dan struktural. Untuk pendekatan kultural digunakan tingkat analisis masyarakat, yakni dengan mengkaji integrasi penduduk miskin dengan lembaga lokal masyarakat. Sedang untuk pendekatan struktural dilihat dari proporsionalitas atau keberpihakan terhadap penduduk miskin terkait kebijakan dan program pembangunan yang dijalankan selama ini.

Setelah melakukan penellitian, peneliti dapat memberikan gambaran bahwa peran pemerintah dalam pengentasan kemiskinan sejauh ini telah dilihat mengalami peningkatan, dimana dengan di bentuknya Layanan Terpadu Penanggulangan Kemiskinan Daerah (LTPKD) merupakan lembaga pemerintah yang melakukan penanggulangan kemiskinan berbasis data terpadu dengan dasar hukum Peraturan Bupati Ciamis Nomor 62 Tahun 2014 tentang Pembentukan Layanan Terpadu Penanggulangan Kemiskinan Daerah.

Komitmen Pemerintah Kabupaten Ciamis terhadap program penanggulangan kemiskinan secara berkelanjutan dan pandangan bahwa perlunya program inovasi penanggulangan kemiskinan berbasis data terpadu merupakan latar belakang digulirkannya Layanan Terpadu Penanggulangan Kemiskinan Daerah (LTPKD).

Dikutip dari Buku Panduan Layanan Terpadu Penanggulangan Kemiskinan Daerah (LTPKD) tujuan dari pembentukan LPTKD adalah:

1. Tersedianya pusat data (database) kemiskinan yang terpadu; 
2. Terintegrasinya tujuan, sasaran, strategi, kebijakan, program dan kegiatan penanggulangan kemiskinan;

3. Terkendalinya proses perencanaan, pelaksanaan, evaluasi dan pelaporan penanggulangan kemiskinan

4. Terbentuknya lembaga yang efektif dan efisien dalam penyelenggaraan penanggulangan kemiskinan.

LTPKD berada di bawah dan bertanggung jawab kepada Bupati Ciamis melalui Sekretaris Daerah Kabupaten Ciamis. Ruang lingkup dari LTPKD adalah pelayanan kepada masyarakat miskin, verifikasi dan pemetaan data kemiskinan dan penentuan kriteria kemiskinan daerah. Adapun tugas pokok LPTKD adalah untuk membantu Bupati dalam rangka percepatan dan penguatan secara terpadu dalam penyusunan kebijakan dan pengordinasian terhadap pelaksanaan pelayanan penanggulangan kemiskinan. Sedangkan fungsi dari LTPKD adalah :

1. Koordinasi pelaksanaan program/kegiatan pelayanan dan penanganan penanggulangan kemiskinan secara terpadu meliputi aspek pendidikan, kesehatan, sosial dan ekonomi serta data dan informasi;

2. Pemantauan dan evaluasi pelaksanaan kebijakan pemerintahan daerah dalam penanggulangan kemiskinan;

3. Pelayanan administrasi penanggulangan kemiskinan;

4. Penanganan pengaduan masyarakat terhadap program/kegiatan penanggulangan kemiskinan;

5. Pengkajian, penghimpunan dan pembaharuan (updating database) kemiskinan. (ST)

2. Kendala-kendala yang dihadapi Pemerintah Kabupaten Ciamis dalam melakukan pengentasan kemiskinan.

Dari hasil survey ke lapangan dapat disimpulkan bahwa terdapat 3 faktor penyebab timbulnya kemiskinan, yaitu faktor individu yang bersangkutan, faktor kebijakan pemerintah, dan faktor alamiah. Masingmasing adalah sebagai berikut :

1. Faktor Individu yang bersangkutan, yakni malas atau mempunyai motivasi yang rendah untuk memanfaatkan potensi ekonomi yang ada pada dirinya dan lingkungan alam sekitarnya, memiliki pengalaman dan 
keterampilan yang rendah untuk menekuni sebuah pekerjaan, dan tidak mempunyai modal.

2. Faktor Kebijakan Pemerintah, meliputi pendapatan rendah, tidak ada lapangan kerja, harga sembako tinggi, pendidikan mahal, sarana dasar kurang, biaya jasa mahal.

3. Faktor alamiah (perjalanan waktu), meliputi Bencana Keluarga, Jompo, Bencana Alam.

Berlatar belakang dari beberapa faktor yang menjadi faktor penyebab kemiskinan yang ada di Kabupaten Ciamis Layanan Terpadu Penanggulangan Kemiskinan Daerah (LTPKD) merupakan lembaga pemerintah yang melakukan penanggulangan kemiskinan berbasis data terpadu. Salah satu kendala yang dihadapi adalah Sistem pengelolaan data kemiskinan daerah untuk pengelolaan dana kemiskinan diperlukan perangkat dan sistem yang terintegrasi hingga ke desa-desa.

Sedangkan di ketahui bahwa LTPKD yang sampai saat ini hanya ada di kabupaten, sehingga keberadaannya baru 1 yakni di Kabupaten Ciamis, sedangkan data yang di perlukan adalah tersebar di berbagai desa. Sudah seharusnya keberadaan Layanan Terpadu Penanggulangan Kemiskinan Daerah (LTPKD). Tidak hanya ada di kabupaten tetapi ada di minimal setiap kecamatan.

Pemerintah Kabupaten Ciamis belum memiliki sistem aplikasi untuk pengelolaan data kemiskinan daerah. Ini yang sedang diprogramkan kedepannya karena data kemiskinan harus bisa dimutakhirkan dengan cepat, akurat yang terintegrasi hingga ke pelosok desa.

\section{Upaya Penanggulangan Kemiskinan Di Kabupaten Ciamis}

Upaya penanggulangan kemiskinan merupakan tanggung jawab kita bersama yang memerlukan dukungan dan peran aktif dari seluruh pihak. Keterlibatan seluruh pelaku pembangunan diharapkan akan mendorong terbangunnya sebuah kesamaan cara pandang, keterpaduan dan komitmen dalam melakukan upaya penanggulangan kemiskinan.

Upaya pengentasan kemiskinan di Kabupaten Ciamis dilakukan melalui dikeluarkannya regulasi peraturan Perundang-undangan yang mengatur mengenai kemiskinan, diantarnya Peraturan Daerah Kabupaten 
Ciamis Nomor 11 Tahun 2016 Tentang Penanggulangan Kemiskinan dan Peraturan Bupati Nomor 29 Tahun 2016 tentang Indikator Lokal Keluarga Miskin Di Kabupaten Ciamis.

Upaya pemerintah dalam penanggulangan kemiskinan dilakukakan baik oleh Pemerintah Pusat maupun oleh Pemerintah daerah. Kebijakan pemerintah dalam pengentasan kemiskinan di Pusat terdiri dari 3 (tiga) program yakni :

a. Bidang Kesehatan

Nama Program Indonesia Sehat, Penyelenggara Badan Penyelenggara Jaminan Sosial, Media Kartu Indonesia Sehat, Cakupan Hingga Satuan Tingkat Desa (POSYANDU), Penerimaan Masyarakat kurang Mampu yang telah memiliki BPJS PBI ditambahkan kelompok Penyandang Masalah Kesejahteraan Sosial (PMKS) serta bayi baru lahir.

b. Bidang Pendidikan

Nama Program Indonesia Pintar, Media Kartu Indonesia Pintar Penerimaan Semua Anak SD/MI, SMP/MTs, SMA/MA, SMK/MAK, yang berasal dari keluarga pemegang KKS/KPS,PKH, Panti Asuhan dan Anak Yatim Piatu.Masyarakat kurang Mampu yang telah memiliki BPJS PBI ditambahn kelompok Penyandang Masalah Kesejahteraan Sosial (PMKS) serta bayi baru lahir, Bentuk Penyalura Simpanan Tabungan di Kantor POS atau Bank yang ditunjuk bisa dicairkan atau tetap disimpan.

c. Bidang Sosial Ekonomi

Nama Program Kesejahteraan Sosial, Media Kartu Kesejahteraan Sosial (KKS), Penerimaan keluarga kurang mampu di seluruh Indonesia, mencakup juga penghuni pantiasuhan, panti jompo, dan panti sosial lainnya, BesaranRp. 200.000,-/Keluarga/Bulan.Bentuk Penyaluran Simpanan / Tabungan di Kantor POS atau Bank yang ditunjuk bisa dicairkan atau tetap disimpan.

Dari penjelasan program diatas yang merupakan program pemerintah Pusat, seiring dengan dikeluarkannnya Undang-Undang Pemerintahan Daerah yang menyatakan adanya kewenangan yang dimiliki 
oleh Pemerintah Daerah diantaranya kewenangan untuk melakukan pengentasan kemiskinan.

Upaya penangggulangan yang dilakukan pemerintah Kabupaten Ciamis dengan merealisasikan ketiga program pemerintah pusat tersebut dalam program pemerintah daerah, program-program tersebut yakni:

1. Program Kesehatan

Program ini merupakan upaya dalam bidang kesehatan masyarakat yang medianya berwujud Kartu Waluya dimulai pada tahun 2016. Cakupan dari program ini jaminan kesehatan seluruh masyarakat miskin, operasi katarak, khitanan masal dan pemberian makanan tambahan (PMT), jumlah anggarannnya sebesar Rp. 3.006.699.150, dimana besaran premi dalam kartu waluya ini yakni Rp. 23.000/Jiwa/Bulan yang di bayarkan ke BPJS Kesehatan, bentuk pelayanan yakni pembayaran Premi ke BPJS Kesehatan dan Pelayanan Langsung Ke Masyarakat, manfaat yang di dapat adalah promitif, preventif, kuratif dan detektsi dini. Adapun realisasi anggaran dan Dana Capaian Kinerja Program Waluya Tahun 2016 yakni :

a. Integrasi Jamkesda

Anggaran Rp. 2.164.234.525 (APBD Ciamis), sasaran 12.207 Jiwa, sisa anggaran Rp. 24.335.075,-, Anggaran 534.831.000,- (Banprop Jawa Barat), Sasaran 12.207 Jiwa, Sisa Anggaran Rp. 173.223.550, Capaian program jamkesda pada tahun 2016 telah terealisasi sesuai target yakni 100\%, sedangkan anggaran mencapai 93\%.

b. Operasi Katarak

Anggaran Rp. 80.550 .000 (APBD Kab. Ciamis), Sasaran 80 Jiwa, Sisa anggaran Tidak ada.

c. Khitanan Massal

Anggaran Rp. 169.822.050,- (APBD Kab. Ciamis), Sasaran 115 Jiwa.

d. Pemberian Makanan Tambahan (PMT)

Anggaran Rp. 187.200.000,- (APBD Kab. Ciamis), Sasaran 160 Jiwa. 
2. Program Pendidikan

Program ini merupakan program yang bermaksud menanggulangi siswa DO dan RDO, program ini beri nama Calakan yang ada pada tahun 2016. Adapun cakupan dari program ini Siswa-siswi SMP, SMA, SMK dari keluarga pemegang KKS/KPS, PKH Panti Asuhan dan Anak Yatim Piatu diluar kuota bantuan siswa miskin (BSM)/ KIP. Penyaluran dana ini melalui simpanan/tabungan di kantor Pos atau Bank yang ditunjuk bisa dicairkan atau tetap di simpan di tabungan. Besaran dana ini, untuk SMP Rp. 750.000/siswa/Tahun untuk 500 siswa, SMA/SMK, sedangkan untuk SMA/SMK Rp. 1.000.000/siswa/tahun untuk 262 siswa.

3. Program Sosial Ekonomi

Program di Kabupaten Ciamis ini di beri nama Subsis Raskin, RUTILAHU. Mencakup subsidi raskin, RUTILAHU serta pembinaan dan pengembangan Bidang ketenagalistrikan, Sasaran bagi Keluarga kurang mampu pemilik KPS dan RTM berdasarkan kriteria khusus. Sebesar Rp. 1000/kg/RTS-PM Rutilahu Rp. 10.000.000/RTM untuk 300 sasaran. Anggaran : Rp. 24.585.648.000, adapun bentuk Penyaluran untuk subsidi RASKIN pembayaran langsung ke PERUM BULOG untuk Rutilahu bantuan langsung ke penerima manfaat, untuk listrik langsung di pasang ke penerima manfaat oleh pihak ketiga (Daftar penerima manfaat di tetapkan oleh keputusan Bupati).

Realisasi program sosial ekonomi di Kabupaten Ciamis dapat dijelaskan bahwa :

a. Program Raskin/Rastra : Anggaran Rp. 16.988.040.000, Subsidi Rp. 3.397.608.000, Angkut sasaran 94.378 RTS, Pencapaian kinerja dan anggaran $100 \%$.

b. Program Rutilahu : Anggaran Rp. 3.090.000.000, Sasaan 309 Rumah, Pencapaian kinerja dan anggaran terealisasi $100 \%$.

c. Program Listrik Pra KS :Target 953 KKK, Terealisasi 953 KK, Pencapaian kinerja dan anggaran terealisasi $100 \%$.

Dari rincian diatas maka dapat dijelaskan bahwa Pemerintah Kabupaten Ciamis dalam upaya penanggulangan pengentasan kemiskinan di Kabupaten Ciamis dilakukan melalui Lembaga Terpadu 
Penanggulangan Kemiskinan Daerah (LTPKD ) dengan Tiga Program Pokok, yang pertama bidang kesehatan yakni program Waluya, dengan pemberian jamkesda, operasi katarak, khitanan massal dan pemberian makanan tambahan. Yang kedua bidang pendidikan yakni Program Calakan dengan pemberian beasiswa untuk 500 siswa SMP dan 262 untuk siswa SMA/SMK. Yang ketiga bidang sosial dan ekonomi yakni Program Walagri di implementasikan dengan program raskin/rastra dan program Rutilahu.

Ketiga program utama dalam rangka upaya pengentasan kemiskinan di Kabupaten Ciamis telah mencapai target realisasi 100\%, sehingga dapat meningkatkan taraf hidup masyarakat miskin meskipun tidak secara signifikan.

Dalam upaya mengurangi permasalahan kemiskinan di masyarakat, telah dilakukan kegiatan road show program penanggulangan kemiskinan di Kabupaten Ciamis. Kegiatan ini dilaksanakan di tiap eks Kawedanaan Wilayah Kabupaten Ciamis selama 5 hari, mulai tanggal 19 -27 April 2016 dan ditujukan kepada seluruh Camat dan Kepala Desa. Kegiatan ini merupakan kegiatan untuk mensosialisasikan program-program secara lebih jelas dan menyeluruh kepada masyarakat Kabupaten Ciamis. Untuk kedepan diharapkan kegiatan ini menjadi agenda rutin dan menjadi salah satu kegiatan LTPKD (Layanan Terpadu Penanggulangan Kemiskinan Daerah).

Selanjutnya dalam upaya mendekatkan layanan kepada masyarakat telah dilakukan pelaksanaan Bhakti Sosial terkait program penanggulangan kemiskinan sekaligus peletakan batu pertama pembangunan Jembatan Ciparay, yang dilaksanakan di Desa Ciparay Kecamatan Cidolog pada Hari Jum'at-Sabtu tanggal 20 - 21 Mei 2016. Kegiatan ini meliputi : Penyuluhan Pembangunan (Sosial Ekonomi, Kesehatan/KB, dan Pendidikan), Pembagian Sembako Kepada Masyarakat Miskin di Desa Ciparay Kecamatan Cidolog dan Desa Margajaya Kecamatan Pamarican, Pengobatan gratis, Pembuatan Kartu Keluarga dan Akte Kelahiran gratis, Pelayanan KB gratis, Donor Darah, dan Perpustakaan gratis. 


\section{PENUTUP}

\subsection{Kesimpulan}

a. Peran Pemerintah dalam pengentasan kemiskinan di Kabupaten Ciamis dengan di bentuknya Layanan Terpadu Penanggulangan Kemiskinan Daerah LTPDK, Dasar Hukum Peraturan Bupati Ciamis Nomor 62 Tahun 2014 tentang Pembentukan Layanan Terpadu Penanggulangan Kemiskinan Daerah.

b. Kendala yang dihadapi pemerintah dalam pengentasan kemiskinan di Kabupaten Ciamis adalah dalam hal Sistem pengelolaan data kemiskinan daerah, untuk pengelolaan dana kemiskinan diperlukan perangkat dan sistem yang terintegrasi hingga ke desa-desa.

c. Upaya Pemerintah daerah dalam pengentasan kemiskinan dengan mengeluarkan regulasi mengenai pengentasan kemiskinan yakni Peraturan Daerah Kabupaten Ciamis Nomor 11 Tahun 2016 Tentang Penanggulangan Kemiskinan, Peraturan Bupati Ciamis Nomor 29 Tahun 2016 tentang Indikator Lokal Keluarga Miskin di Kabupaten Ciamis, serta merealisasikan 3 (Tiga) program utama yakni, Bidang Kesehatan "Waluya", Bidang Pendidikan "Calaka", Bidang Sosial Ekonomi "Walagri”.

\subsection{Saran}

a. Pemerintah Kabupaten Ciamis lebih intens melakukan pengentasan kemiskinan sehingga taraf hidup keluarga miskin semakin menurun.

b. Pemerintah segera membentuk Layanan Terpadu Penanggulangan Kemiskinan Daerah di setiap kecamatan sehingga membantu pendataan yang lebih relevan.

\section{DAFTAR PUSTAKA}

Bappenas. 2004. Rencana Strategik Penanggulangan Kemiskinan di Indonesia : Jakarta.

Nanga, M. 2006. Dampak Transfer Fiscal terhadap Kemiskinan di Indonesia. Jakarta : World Bank.

Nazir, M. 1998. Metodologi Penelitian Pembangunan Desa. Jakarta : Bina Aksara. 
Parwato. 2001. Penanggulangan Kemiskinan Departemen Permukiman dan Pembangunan Sarana. Jakarta : Wilaya.

Soerjono Soekanto. 1986. Pengantar Penilitian Hukum. Jakarta : UI Press.

Soetrisno L. 2001. Kemiskinan, Perempuan dan Pemberdayaan. Yogyakarta: Kanisius.

Sukirno, Sadono. 2002. Ekonomi Pembangunan Proses Masalah dan Dasar- dasar Kebijaksanaan. Jakarta : Universitas Indonesia.

Suharto ES. 2003. Kemiskinan dan Keberfungsian Sosial. Bandung: STKS Press.

Sunaryo, Urip. 2007. Perkembangan jumlah penduduk miskin dan penyebabnya. Badan Pusat Statistik, Jakarta.

Triana, Lidya. 2006. Faktor-faktor yang mempengaruhi tingkat kemiskinan di Indonesia: Analisis data susenas 2004.

Winarno, Wing Wahyu. 2009. Analisis Ekonometrika Dan Statistika Dengan Eviews. Edisi kedua. UPP STIM YKPN. Yogyakarta. 